\title{
. \\ Compare the Levels of Use of Activated Carbons for Water Treatment and Biogas Purification as Well as Their Reactive Abilities
}

\author{
Lukasz Winconek (D) and Katarzyna Ignatowicz *(D)
}

check for updates

Citation: Winconek, Ł.; Ignatowicz, K. Compare the Levels of Use of Activated Carbons for Water Treatment and Biogas Purification as Well as Their Reactive Abilities. Environ. Sci. Proc. 2021, 9, 8. https:// doi.org/10.3390/environsciproc 2021009008

Academic Editors: Dorota Anna Krawczyk, Iwona Skoczko, Antonio Rodero Serrano and Ewa Szatyłowicz

Published: 14 October 2021

Publisher's Note: MDPI stays neutral with regard to jurisdictional claims in published maps and institutional affiliations.

Copyright: (c) 2021 by the authors. Licensee MDPI, Basel, Switzerland. This article is an open access article distributed under the terms and conditions of the Creative Commons Attribution (CC BY) license (https:// creativecommons.org/licenses/by/ $4.0 /)$.
Faculty of Civil and Environmental Sciences, Bialystok University of Technology, Wiejska 45A, 15-351 Białystok, Poland; winconekl@grand-activated.pl

* Correspondence: k.ignatowicz@pb.edu.pl

+ Presented at Innovations-Sustainability-Modernity-Openness Conference (ISMO'21), Bialystok, Poland, 14 May 2020.

\begin{abstract}
The conducted research concerned a comparison of the levels of use of activated carbons purifying water and biogas, and their reactivation capacity. The process of reactivation of both activated carbons was carried out using laboratory kiln. Reactivation was carried out in identical conditions for both tested samples. The obtained results proved that both activated carbons can be regenerated although they differ significantly in degree of use. It was proven that the technological process, the degree of contamination, and the contact time of activated carbon with the medium have a significant impact on the quality, speed, and success of the reactivation process.
\end{abstract}

Keywords: activated carbon; water treatment; biogas production; regeneration; reactivation; iodine number; mechanical strength; surface area; environmental engineering

\section{Introduction}

Activated carbon (AC) is a porous material with a large specific surface area and increased pore volume. The activated carbon structure is a disordered pore system with a diameter of less than one to several hundred nanometers. AC has a large specific surface area (up to $1200 \mathrm{~m}^{2} / \mathrm{g}$ ) and a significant pore volume (even above $1 \mathrm{~cm}^{3} / \mathrm{g}$ ) [1-6]. They are made on the basis of various raw materials, such as coal, charcoal, peat, anthracite, coconut shells, beet molasses, and palatinose and can take various forms: dusty, granular, and formed [3-8]. AC is used in many industries, for example dietary supplementation, pharmaceutical industry, synthesis, electroplating industry, water treatment, exhaust gas, and waste gas treatment $[1,3,9-11]$.

\section{Material and Methods}

We collected three samples of activated carbon (WG-12(W), WG-12(S), and NG-II). The first and the second one was used in the water treatment process for four years (in various water treatment plants, where (S)—Szczecin, (W) -Warsaw), the third in the purification of biogas from siloxanes for two months (Krzywa-biogas plant). Samples differed essentially from two components: grain size and time of work in the process. Other components such as the origin of raw materials, production technology, and physicochemical parameters were comparable. The parameters of three active carbons are presented in Table 1. 
Table 1. The parameters of new activated carbon (WG-12 and NG-II).

\begin{tabular}{ccccccc}
\hline $\begin{array}{c}\text { Activated } \\
\text { Carbon }\end{array}$ & $\begin{array}{c}\text { Iodine Number } \\
{[\mathbf{m g} / \mathbf{g}]}\end{array}$ & $\begin{array}{c}\text { Surface } \\
\text { Area }\left[\mathbf{m}^{2} / \mathbf{g}\right]\end{array}$ & $\begin{array}{c}\text { Mechanical } \\
\text { Strength [\%] }\end{array}$ & $\begin{array}{c}\text { Bulk Density } \\
{[\mathbf{g} / \mathrm{L}]}\end{array}$ & $\begin{array}{c}\text { Ash Content } \\
{[\%]}\end{array}$ & $\begin{array}{c}\text { Volatile Parts } \\
\text { Content [\%] }\end{array}$ \\
\hline WG-12 (W) & 1058 & 1001 & 97.8 & 454 & 14.3 & 7.4 \\
WG-12 (S) & 1072 & 1012 & 97.7 & 442 & 14.1 & 8.1 \\
NG-II & 1024 & 952 & 99.9 & 467 & 14.6 & 8.8 \\
\hline
\end{tabular}

Activated carbons was dried and analyzed to determine the degree of use. The results are presented in Table 2.

Table 2. The parameters of used activated carbon (WG-12-water treatment, NG-II—biogas).

\begin{tabular}{ccccccc}
\hline $\begin{array}{c}\text { Activated } \\
\text { Carbon }\end{array}$ & $\begin{array}{c}\text { Iodine Number } \\
{[\mathbf{m g} / \mathbf{g}]}\end{array}$ & $\begin{array}{c}\text { Surface Area } \\
{\left[\mathbf{m}^{2} / \mathbf{g}\right]}\end{array}$ & $\begin{array}{c}\text { Mechanical } \\
\text { Strength [\%] }\end{array}$ & $\begin{array}{c}\text { Bulk Density } \\
{[\mathbf{g} / \mathbf{L}]}\end{array}$ & $\begin{array}{c}\text { Ash Content } \\
{[\%]}\end{array}$ & $\begin{array}{c}\text { Volatile Parts } \\
\text { Content [\%] }\end{array}$ \\
\hline WG-12 (W) & 346 & 267 & 97.1 & 583 & 13.7 & 22.8 \\
WG-12 (S) & 523 & 451 & 96.1 & 501 & 10.2 & 14.9 \\
NG-II & 32 & 1 & 99.9 & 655 & 13.6 & 41.3 \\
\hline
\end{tabular}

The research involved reactivating three activated carbon samples using the same process conditions. The test stand consisted of a stationary dryer and a laboratory kiln. Prepared and standardized tests in the amount of $0.1 \mathrm{dm}^{3}$ were mounted in a pipe made of steel wire with a mesh of $0.5 \mathrm{~mm}$ and subjected to the reactivation process at $850{ }^{\circ} \mathrm{C}$ for $20 \mathrm{~min}$ [12]. The experiment was replicated three times to reach reliable results.

\section{Results and Discussion}

Table 3 presents obtained results of re-activated carbons.

Table 3. The parameters of re-activated carbon (WG-12-water treatment, NG-II-biogas).

\begin{tabular}{ccccccc}
\hline $\begin{array}{c}\text { Activated } \\
\text { Carbon }\end{array}$ & $\begin{array}{c}\text { Iodine Number } \\
{[\mathbf{m g} / \mathbf{g}]}\end{array}$ & $\begin{array}{c}\text { Surface Area } \\
{\left[\mathbf{m}^{\mathbf{2}} \mathbf{g}\right]}\end{array}$ & $\begin{array}{c}\text { Mechanical } \\
\text { Strength [\%] }\end{array}$ & $\begin{array}{c}\text { Bulk Density } \\
{[\mathbf{g} / \mathbf{L}]}\end{array}$ & $\begin{array}{c}\text { Ash Content } \\
{[\%]}\end{array}$ & $\begin{array}{c}\text { Volatile Parts } \\
\text { Content [\%] }\end{array}$ \\
\hline WG-12 (W) & 587 & 505 & 96.1 & 511 & 17.6 & 7.2 \\
WG-12 (S) & 841 & 776 & 93.7 & 427 & 11.6 & 4.2 \\
NG-II & 914 & 847 & 99.6 & 504 & 17.4 & 5.7 \\
\hline
\end{tabular}

The results obtained show the reactivity of each sample tested. The obtained results showed that both activated carbons can be regenerated, although they differ significantly in the degree of elaboration. The highest reactivation rate was obtained for NG-II carbon, while the lowest for WG-12 (W). It was noted that the degree of regeneration is different for the same sorbent operating under different conditions. It has been shown that the technological process, the degree of contamination and the contact time of activated carbon with the purified medium have a significant impact on the quality, speed, and success of the reactivation process. There was no significant effect of the reactivation process on the mechanical strength of the tested activated carbons. The efficiency of processes differed significantly from each other.

\section{Conclusions}

1. The highest reactivation rate was obtained for NG-II carbon, while the lowest for WG-12 (W).

2. It was noted that the regeneration capacity is different for the same type of activated carbon operating under different conditions.

3. The efficiency of the regeneration process largely depends on the degree of use of activated carbon. 
Author Contributions: Ł.W. and K.I. conceived and designed the experiments; $Ł . W$. performed the experiments; Ł.W. and K.I. analyzed the data; Ł.W. contributed materials; Ł.W. wrote the paper. All authors have read and agreed to the published version of the manuscript.

Institutional Review Board Statement: Not applicable.

Conflicts of Interest: The authors declare no conflict of interest.

\section{References}

1. Bansal, R.C.; Goyal, M. Adsorpcja na węlu aktywnym. In Adsorption on Activated Carbon; WNT: Warszawa, Poland, 2009.

2. Dębowski, Z. Wẹgiel aktywny w ochronie środowiska i przemyśle. In Activated Carbon in Environmental Protection and Industry; Wydawnictwo Politechniki Częstochowskiej: Częstochowa, Poland, 2004.

3. Jankowska, H.; Świątkowski, A.; Starostin, L.; Ławinienko-Omiecynska, J. Adsorpcja jonów na węglu aktywnym. In Ion Adsorption on Activated Carbon; Wydawnictwo Naukowe PWN: Warszawa, Poland, 1991.

4. Ignatowicz, K.; Piekarski, J.; Skoczko, I.; Piekutin, J. Analysis of simplified equations of adsorption dynamics of HCH. Desalin. Water Treat. 2016, 57, 1420-1428. [CrossRef]

5. Filipkowska, U.; Jóźwiak, T.; Bugajska, P.; Skrodzka, A. Effect of Chitin Modification on the Sorption Efficiency of Reactive Black 5 Dye. Rocznik Ochrona Środowiska 2018, 20, 616-633.

6. Ignatowicz, K. Sorption process for migration reduction of pesticides from graveyards. Arch. Environ. Prot. 2008, 34, 143-149.

7. Ruthven, D.M. Principles of Adsorption and Adsorptionprocess; John Wiley \&Sons Inc.: New York, NY, USA, 2020.

8. Ignatowicz, K. Hexachlorocyclohexane $(\mathrm{HCH})$ isomers adsorption from water solution using natural sorbent. Desalin. Water Treat. 2018, 134, 1420-1428. [CrossRef]

9. Kuśmierek, K.; Bieniek, K.; Dąbek, L.; Świątkowski, A. Adsorption of Halogenophenols from Aqueous Solutions on Activated Carbon. Ann. Set Environ. Prot. 2017, 19, 355-369.

10. Piekarski, J.; Dabrowski, T.; Ignatowicz, K. Effect of bed height on efficiency of adsorption of odors from sewage sludge using modified biochars from organic waste materials as an adsorbent. Desal. Water Treat. 2021, 218, 252-259. [CrossRef]

11. Rouquerol, J. Adsorption by Powders and Porous Solids; Academic Press, Elsevier Books: Cambridge, MA, USA, 2013.

12. Duong, D. Adsorption Analysis: Equilibria and Kinetics; Imperial College Press: London, UK, 1997. 